Elsevier required licence: (C) <2017>. This manuscript version is made available under the CC-BY-NC-ND 4.0 license http://creativecommons.org/licenses/by-nc-nd/4.0/ 


\section{The role of microbial diversity and composition in minimizing sludge production in the oxic-settling-anoxic (OSA) process}

June 2017

Revised manuscript submitted to

Science of the Total Environment

Galilee U. Semblante ${ }^{\text {a }}$, Hop V. Phan ${ }^{\text {a }}$, Faisal I. Hai ${ }^{\text {a*, }}$ Zhi-Qiang Xu ${ }^{\text {b }}$, William E. Price ${ }^{\text {c }}$, and Long D. Nghiem ${ }^{\text {a }}$

${ }^{a}$ Strategic Water Infrastructure Laboratory, School of Civil, Mining and Environmental

Engineering, University of Wollongong, Wollongong, NSW 2522, Australia

${ }^{\mathrm{b}}$ Centre for Medical and Molecular Bioscience, University of Wollongong, Wollongong, NSW 2522, Australia

${ }^{c}$ Strategic Water Infrastructure Laboratory, School of Chemistry, University of Wollongong, Wollongong, NSW 2522, Australia

* Corresponding author:

Email: faisal@uow.edu.au,Ph:+61242213054

\section{Abstract}

The oxic-settling-anoxic (OSA) process, which involves an aerobic tank attached to oxygenand substrate-deficient external anoxic reactors, minimizes sludge production in biological wastewater treatment. In this study, the microbial community structure of OSA was determined. Principal coordinate analysis showed that among the three operational factors, i.e., (i) redox condition, (ii) external reactor sludge retention time ( $\mathrm{SRT}_{\text {ext }}$ ), and (iii) sludge interchange between aerobic and anoxic reactors, redox condition had the greatest impact on microbial diversity. Generally, reactors with lower oxidation-reduction potential had higher microbial diversity. The main aerobic sequencing batch reactor of OSA (SBR $\left.{ }_{O S A}\right)$ that interchanged sludge with an external anoxic reactor had greater microbial diversity than SBR $_{\text {control }}$ which did not have sludge interchange. SBR osA sustained high abundance of the slow-growing nitrifying bacteria (e.g., Nitrospirales and Nitrosomondales) and consequently exhibited reduced sludge yield. Specific groups of bacteria facilitated sludge autolysis in the external reactors. Hydrolyzing (e.g., Bacteroidetes and Chloroflexi) and fermentative (e.g., 
Firmicutes) bacteria, which can break down cellular matter, proliferated in both the external aerobic/anoxic and anoxic reactors. Sludge autolysis in the anoxic reactor was enhanced with the increase of predatory bacteria (e.g., order Myxobacteriales and genus Bdellovibrio) that can contribute to biomass decay. Furthermore, $\beta$ - and $\gamma$-Proteobacteria were identified as the bacterial phyla that primarily underwent decay in the external reactors.

Keywords: microbial community analysis, fermentative bacteria, hydrolyzing bacteria, Illumina sequencing, oxidation-reduction potential, predatory bacteria

\section{Introduction}

The management of excess sludge constitutes a significant fraction (up to 60\%) of the total operation cost of biological wastewater treatment. Because sludge contains active biomass and biodegradable materials, treatment is required prior to disposal to prevent negative impact on public sanitation and environment. Sludge treatment, which mainly involves the removal of water, volatile solids, and pathogens, is a challenging process due to the strong binding of water molecules to sludge flocs and the slow biodegradation of the volatile fraction under ambient conditions (Mowla et al., 2013; Tchobanoglus et al., 2003). Furthermore, there are only a few options for ultimate sludge disposal. Ocean-dumping and land-filling were the traditional means of disposing of sludge; however, the former has been banned to protect marine life and while the latter has been restricted due to the high cost of landfill operation. Current practices, such as sludge incineration and re-use of sludge as landapplicable biosolids, have some inherent disadvantages. For instance, incinerating sludge is highly effective in removing volatile solids, but has high energy requirements. Re-using sludge enables the recovery of organic matter and nutrients, but the conversion of sludge into 
high-quality biosolids that can be safely used in agricultural applications and the transport of biosolids from metropolitan facilities to farmlands are expensive (Semblante et al., 2014; Tchobanoglus et al., 2003). These concerns emphasize the need to minimize sludge production. Reducing sludge will decrease costs for dewatering, stabilization, transportation, and other aspects of sludge management (Foladori et al., 2010; Semblante et al., 2014). A number of approaches have been devised to minimize sludge, such as controlling dissolved oxygen (DO) and sludge retention time (SRT) of the aeration tank, adding chemicals to decrease sludge growth, and destroying sludge using advanced oxidation processes. However, the full-scale implementation of these approaches are hindered because they either require significant capital and operating cost or only result in a marginal sludge reduction (Foladori et al., 2010).

The oxic-settling-anoxic (OSA) process is a potentially economical alternative to sludge reduction. It involves the addition of external anoxic reactor/s in the return sludge loop of the conventional activated sludge (CAS) process. Due to its simple design, OSA can be set up using readily available equipment (e.g., tanks, pipes, and pumps) and requires minimal maintenance (Semblante et al., 2014). The sludge interchange between the external anoxic reactor/s and the main aerobic tank results in net sludge reduction. Recent research demonstrated that manipulating parameters such as oxidation-reduction potential (ORP), sludge interchange rate and external reactor SRT influences the autolysis of sludge in the oxygen- and substrate-deficient external anoxic reactor/s (Khursheed et al., 2015; Saby et al., 2003; Semblante et al., 2016b). Sludge can be reduced by more than $35 \%$ depending on the aforementioned parameters and wastewater characteristics (Saby et al., 2003; Semblante et al., 2015). 
Previous studies hypothesized that sludge reduction in the OSA process is driven by the selection of a distinct microbial community brought about by the interchange of sludge between different redox regimes (Goel and Noguera, 2006; Kim et al., 2012; Semblante et al., 2014). Conventional techniques such as polymerase chain reaction-denaturing gradient gel electrophoresis have shown that the microbial community in an oxic-settling-anaerobic system was similar to that of anaerobic digesters, therefore reactions such as sulfate reduction and methane production took place in the external anaerobic reactor (Kim et al., 2012; Saby et al., 2003). High-throughput sequencing methods (i.e., pyrosequencing and Illumina sequencing) produce higher resolution than conventional techniques and hence achieve better characterization of microbial communities. Application of pyrosequencing analysis showed that an aerobic/anoxic system with external anaerobic reactor has greater microbial diversity than a control aerobic/anoxic system (Ning et al., 2014; Zhou et al., 2015) probably because slow-growing fermentative (Azospira, Propionivibrio and Sulfuritalea) (Zhou et al., 2015) and hydrolyzing (Sphingobacteria) (Ning et al., 2014) bacteria were enriched under anaerobic conditions. Meanwhile, Illumina sequencing analysis in the study by Cheng et al. (2017) showed enrichment of different types of bacteria in an aerobic membrane bioreactor (MBR), e.g., Nitrospirae, and the attached external anaerobic reactor, e.g., Chloroflexi and Armatimonadetes. It was further observed that microbial groups that facilitate sludge autolysis, such as those that perform degradation of extracellular polymeric substances (EPS), sulphate reduction, and fermentation, survive in the external anaerobic reactor attached to an anoxic/aerobic sequencing batch reactor (SBR) (Cheng et al., 2017; Ferrentino et al., 2016). These studies imply that aerobic-anaerobic interchange enriched sludge biomass and that microbial composition yielded useful information regarding potential biological reactions relevant to sludge reduction (Cheng et al., 2017; Ferrentino et al., 2016; Ning et al., 2014; Zhou et al., 2015). Therefore, it is necessary to characterize the microbial community 
structure of OSA, which is expected to differ from that of other configurations available in literature due to the sensitivity of bacteria to redox and other operating conditions, to understand its effects on sludge reduction. Addressing this crucial knowledge gap will be useful in designing bioreactors and selecting operating conditions that will facilitate sludge reduction.

The aim of this study was to determine the microbial community structure in OSA to provide insight in its role in sludge reduction mechanisms. A laboratory-scale OSA (SBR with external aerobic/anoxic and anoxic reactors) with real wastewater was operated alongside a control (SBR with single-pass aerobic digester). To systematically determine the effects of microbial community on sludge reduction, Illumina sequencing analysis was performed when

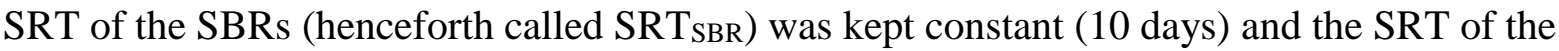
external reactors (henceforth called SRT $\mathrm{ext}_{\text {) }}$ were varied $(10,20$, and 40 days). The potential linkage between operating parameters $\left(e . g .\right.$, redox condition, $\mathrm{SRT}_{\mathrm{ext}}$, and sludge interchange between aerobic and anoxic reactors) and microbial community was determined. Variation in microbial diversity and taxonomic classifications were also systematically investigated.

\section{Materials and methods}

\subsection{Wastewater characteristics}

Wastewater was obtained fortnightly from the beginning of the primary sedimentation channel of Wollongong wastewater treatment plant (WWTP), New South Wales, Australia. It was stored at $4{ }^{\circ} \mathrm{C}$ in plastic containers prior to use. Wastewater characteristics are summarized in Supplementary Table S1.

\subsection{Reactor configuration and operation}


The detailed description of the configuration and operation of the OSA and control systems is discussed elsewhere (Semblante et al., 2016b). Briefly, the OSA system consisted of a SBRosa (5 L) attached to external aerobic/anoxic (2 L) and anoxic reactors (2 L) (Figure 1a). The control system consisted of $\mathrm{SBR}_{\text {control }}(5 \mathrm{~L})$ attached to a single-pass aerobic digester (2 L) (Figure 1b).

\section{[Figure 1]}

SBR $_{\text {control }}$ and SBRosA were fed with domestic sewage (Section 2.1) and operated at 4 cycles/day and HRT of $12 \mathrm{~h}$. Each cycle comprised of $15 \mathrm{~min}$ of filling, $4.5 \mathrm{~h}$ of aeration, $1 \mathrm{~h}$ of settling, and 15 min of decanting. The SRT of SBR control $_{\text {and }} \mathrm{SBR}_{\mathrm{OSA}}$ were maintained at 10 days by regular sludge wastage (W) (Figure 1).

The aerobic digester of the control system (Figure 1a) was continuously aerated. The SRT of this digester was adjusted to 40, 20, and 10 days at Phase I, II, and III of the study, respectively, through sludge wastage $\left(\mathrm{Q}_{\text {out }}\right)$. The aerobic digester was fed from sludge obtained from $\mathrm{SBR}_{\text {control }}$ thickened to $5-10 \mathrm{~g} / \mathrm{L}\left(\mathrm{q}_{1}\right)$ by centrifugation for $10 \mathrm{~min}$ at $3,300 \mathrm{x} g$. Sludge was obtained from the $\mathrm{SBR}_{\text {control }}$ near the end of its aeration phase (e.g., at $4.5 \mathrm{~h}$ ) to ensure that the majority of the total chemical oxygen demand (tCOD) had been consumed.

The aerobic/anoxic reactor of the OSA system was intermittently aerated (i.e., 8/16 hours aeration on/off). The aerobic/anoxic reactor was fed with sludge from SBR OSA thickened to $5-10 \mathrm{~g} / \mathrm{L}\left(\mathrm{q}_{1}\right)$ by centrifugation for $10 \mathrm{~min}$ at 3,300 $\mathrm{x}$. Sludge was obtained from the SBRosa near the end of its aeration phase (e.g., at $4.5 \mathrm{~h})$ to ensure that the majority of tCOD had been consumed. One-third of sludge from the aerobic/anoxic reactor was transferred to the anoxic reactor $\left(\mathrm{q}_{2}\right)$, and the rest was discharged $\left(\mathrm{q}_{3}\right)$. A sufficient amount was discharged from the external aerobic/anoxic reactor to adjust $\mathrm{SRT}_{\text {ext }}$ at 40,20, and $10 \mathrm{~d}$ at Phase I, II, and 
III of the study. Sludge from the anoxic reactor was returned to the aerobic/anoxic reactor $\left(\mathrm{q}_{4}\right)$ and SBRosA $\left(\mathrm{q}_{5}\right)$.

\subsection{Calculations}

\subsubsection{Sludge yield}

Sludge reduction was determined by comparing the sludge yield of the SBRs under parallel conditions, i.e., same experimental phase (Semblante et al., 2016b). The sludge yield $(Y)$ of the SBR was defined as

$Y=\frac{P}{C}=\frac{g M L V S S}{g t C O D}$

Equation 1

where $P$ is the sludge produced in terms of mixed liquor volatile suspended solids (MLVSS) and $C$ is the substrate consumed in terms of tCOD. Sludge yield was derived from the slope of the linear regression of the cumulative sludge produced versus the cumulative substrate consumed. The detailed calculation of sludge production and substrate consumption is provided in Supplementary Table S2.

Sludge reduction was calculated as the difference in sludge yield of SBR $\mathrm{Control}_{\text {and }}$ SBR $\mathrm{OSA}$ :

Sludge reduction $(\%)=\frac{Y_{S B R_{\text {control }}}-Y_{S B R_{O S A}}}{Y_{S B R_{\text {control }}}} \times 100$

\subsubsection{Nitrification and denitrification efficiency}

Nitrification and denitrification efficiency in the external aerobic/anoxic reactor was estimated as the difference in the ammonia (Equation 3) and nitrate (Equation 4) concentrations, respectively, of the sludge supernatant entering and leaving the reactor. 


$$
\begin{array}{cc}
\text { Nitrification }(\%)=\frac{N H_{4_{\text {in }}}^{+}-N H_{4_{\text {out }}}^{+}}{N H_{4_{\text {in }}}^{+}} \times 100 & \text { Equation } 3 \\
\text { Denitrification }(\%)=\frac{N O_{3_{\text {in }}}^{-}-N O_{3_{\text {out }}}^{-}}{N O_{3_{\text {in }}}^{-}} \times 100 & \text { Equation } 4
\end{array}
$$

\subsection{Wastewater and sludge analysis}

The total and volatile suspended solids (TSS and VSS) of influent and effluent and the MLSS and MLVSS of sludge were measured according to the APHA Standard Method 2540 (Eaton et al., 2005). The sludge volume index (SVI) was measured using $1000 \mathrm{~mL}$ of sludge according to APHA Standard Method 2710-D (Eaton et al., 2005). The tCOD of the influent and effluent was measured using Hach low range (LR) digestion vials that were heated in Hach DBR200 COD Reactor, and then analyzed using Hach DR/2000 spectrophotometer (program number 430 COD LR) according to the APHA Standard Method 5220 (Eaton et al., 2005). Ammonia and phosphate were measured using flow injection analysis (Lachat Instruments, USA) following the APHA Standard Method 4500 (Eaton et al., 2005). The DO concentration of sludge was measured using a DO meter (YSI, USA). The $\mathrm{pH}$ and ORP of sludge were measured with a pH/ORP meter (TPS, Australia).

\subsection{Microbial community analysis}

\subsubsection{DNA extraction and 16S rRNA gene amplicon sequencing}

Sludge samples were collected from all the reactors from both the control and OSA systems at the end of Phase I, II, and III of the study (Section 2.2). Samples were stored and processed following the method described in Phan et al.(Phan et al., 2016). Briefly, DNA extraction was carried out using the FastDNA spin kit for soil (MP Biomedical, New South Wales, 
Australia). DNA integrity and quality were assessed using 1\% agarose gel electrophoresis and a Nanodrop ND-1000 spectrophotometer (NanoDrop Technologies, Wilmington, DE).

Nucleotide sequence determination of the extracted genomic DNA was carried out by the Australian Genome Research Facility (Brisbane, QLD, Australia). The V3-V4 regions of the $16 S$ rRNA gene were amplified using primer pairs: $341 \mathrm{~F}\left(5^{\prime}-C T A Y G G G R B G C A S C A G-3^{\prime}\right)$ and 806R (5'-GGACTACNNGGGTATCTAAT-3'). Amplicon sequencing was conducted on the Illumina MiSeq platform, utilizing Illumina's Nextera XT Index and Paired End sequencing technology. All sequence data in this study are available at the Sequence Read Archive (SRP078298) in the National Centre for Biotechnology Information (U.S. National Library of Medicine).

\subsubsection{Sequence analyses}

Paired-ends reads were assembled by aligning the forward and reverse reads using PEAR (version 0.9.8). Primers were removed using Septk (version 1.2). The sequences were then processed using QIIME (version 1.9.1) (Caporaso et al., 2010b) and USEARCH (version 8.1.1861) (Edgar, 2013) software packages. Following UPARSE pipeline, sequences were trimmed to a fixed length of 240 bases and the reads with expected number of base call errors exceeding 0.5 were eliminated. Full length duplicates were discarded and sorted by abundance. Singletons were removed from the data set. Sequences were clustered followed by chimera filtering using the "rdp_gold" database as reference. Reads were mapped back to OTUs with a minimum identity of 97\%. Taxonomy was assigned by uclust (Edgar, 2010) using the Silva119 database (Pruesse et al., 2007) in QIIME. Representative sequences were aligned using PyNAST (Caporaso et al., 2010a) followed by gap filtering and then used to build phylogeny trees by FastTree (Price et al., 2010). 
The $\alpha$ - and $\beta$-diversities were measured at even sequencing depth of 50,000 sequences per sample (minimum number of sequences found among samples). $\alpha$-diversity indices include observed species, Chao1, phylogenetic diversity (PD_whole_tree) and Shannon. The completeness of sampling was estimated by Good's coverage. For $\beta$-diversity comparison, an unweighted UniFrac distance (Lozupone and Knight, 2005) was calculated and then interpreted by principal coordinate analysis (PCoA). All analyses were carried out in QIIME.

To explain phylogenetic variation of samples, constrained analysis of principal coordinates (CAP) (Anderson and Willis, 2003) and permutational multivariate analysis of variance using distance matrices (Adonis) were carried out. CAP uses a linear model combining several environmental variables (i.e., redox condition, $\mathrm{SRT}_{\mathrm{ext}}$, and sludge interchange between aerobic and anoxic reactors) to predict the unweighted UniFrac coordinates. The significance of the factors in the CAP model was ascertained using analysis of variance (ANOVA). Adonis with 999 permutations was used to supplement tests for significant differences in the community structure between redox, SRT and treatment conditions. The analysis was conducted using phyloseq (McMurdie and Holmes, 2013) and vegan packages (v2.3-5) (Oksanen et al., 2013) in the $R$ environment (http://www.r-project.org/).

\section{Results and discussion}

\subsection{OSA performance}

The highest sludge reduction (35\%) was observed at $\mathrm{SRT}_{\mathrm{ext}}$ of $20 \mathrm{~d}$ (Table 1). Increasing $\mathrm{SRT}_{\text {ext }}$ from 10 to $20 \mathrm{~d}$ enhanced the autolysis of sludge under environmental stress (i.e., oxygen- and substrate- deficient) conditions. However, further increasing $\mathrm{SRT}_{\mathrm{ext}}$ to $40 \mathrm{~d}$ did not improve autolysis; rather it deteriorated nitrification/denitrification efficiency in the external aerobic/anoxic reactor (Supplementary Table S3), indicating that these biological reactions were vital to the conversion of destroyed solids into inert products (Semblante et al., 2016b). Additionally, OSA did not hamper wastewater treatment in the main aeration tank. 


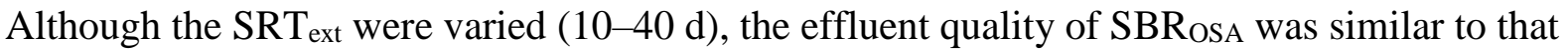
of $\mathrm{SBR}_{\text {control }}$ (Table 1) in terms of COD, ammonia, and orthophosphate (Semblante et al., 2016b). These findings strengthen previous assertions that OSA had no effect on wastewater treatment efficiency (Chen et al., 2003; Saby et al., 2003).

\section{[Table 1]}

\subsection{Microbial diversity}

\subsubsection{Comparison of SBRosA and $\mathrm{SBR}_{\text {control microbial diversity }}$}

The relationship between microbial community and sludge reduction in OSA was systematically investigated by comparing the diversity indices of SBRosA (labeled as SBRO)

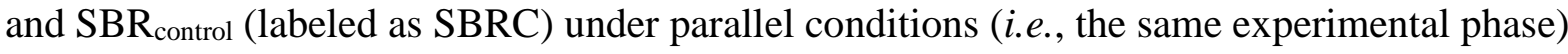
(Table 2). This approach eliminated potential effects of temporal characteristic variations of real wastewater (Supplementary Table S1) on the microbial communities. Since the SBRs were fed with the same wastewater, the only difference between the two tanks at any particular phase was that SBR OSA (Figure 1a) interchanged sludge with the external reactors whereas $\mathrm{SBR}_{\text {control }}$ (Figure 1b) did not have sludge interchange.

SBRosa was more diverse than SBR $_{\text {control when }}$ SRT $_{\text {ext }}$ was 20 (Phase II) and 40 (Phase I) d (Table 1). It was also during these operation periods that the highest diversity indices were recorded for the external anoxic reactor (labeled as ANX) (Table 2). This suggests that the microbial makeup of SBR SSA $_{\text {was }}$ influenced by the continuous loading of sludge from the external anoxic reactor (Figure 1a). In fact, some microbial species were detected exclusively in the OSA system (to be discussed in detail in Section 3.4). Nonetheless, high diversity did not necessarily translate to high sludge reduction. For example, SBRosA had greater diversity than $\mathrm{SBR}_{\text {control }}$ when $\mathrm{SRT}_{\text {ext }}$ was $40 \mathrm{~d}$ (Phase I; Table 2) yet the reactors had similar sludge 
yield (Table 1). A decline in sludge production has been correlated with an increase in microbial diversity in micro-aerobic tanks (Ning et al., 2014), but how they are connected has not been clarified in literature. Current findings suggest that the microbial community structure of SBRosA shifted to contain more slow-growing bacteria such as nitrifiers (to be discussed in Section 3.4.3). These slow growers possibly contribute to the low sludge production rate of $\mathrm{SBR}_{\mathrm{OSA}}$ relative to $\mathrm{SBR}_{\text {control. }}$ However, the increase in microbial diversity

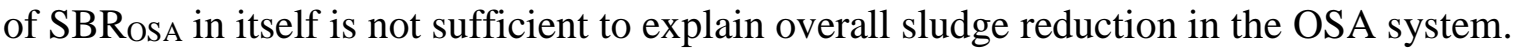
There is also evidence that cryptic-lysis growth (i.e., sludge autolysis followed by conversion of destroyed solids into inert products) (Semblante et al., 2016a) is an important sludge reduction mechanism in OSA. This is driven by the decay and proliferation of distinct microbial groups in the external reactors. These microbial groups are discussed in more detail in Section 3.4.3.

[Table 2]

\subsubsection{Microbial diversity of SBR 0 A and attached external reactors}

To determine the relationship between $\mathrm{SRT}_{\text {ext }}$ and microbial community in OSA, the microbial diversity indices of the OSA system (SBROSA and the attached aerobic/anoxic and anoxic reactors) were compared under parallel conditions. The order of increasing diversity was the same at all $\mathrm{SRT}_{\text {ext: }} \mathrm{SBR}_{\mathrm{OSA}}<$ intermittent aerobic/anoxic (labeled as AE/ANX) < anoxic. This suggests that diversity was affected by redox condition or ORP level. A decrease in ORP generally indicates the depletion of DO in the mixed liquor (Table 3). The diversity of activated sludge (Ning et al., 2014; Stadler and Love, In press; Yadav et al., 2014) and other biological matrices (e.g., marine estuaries) (Spietz et al., 2015) has been found to intensify when DO concentrations decrease. Microbial diversification at low DO concentration has been primarily attributed to the enrichment of facultative anaerobes (Yadav 
et al., 2014) and other microbial groups that can thrive with limited oxygen, though other factors such as appearance of ciliated protozoa (Singh et al., 2016) and bacterial predators (Spietz et al., 2015) are potentially relevant as well. In the current study, unique phyla that encompass fermentative, hydrolyzing and predatory bacteria were detected at low DO concentrations (to be discussed in Section 3.4).

\section{[Table 3]}

Bacteria must be exposed to starvation conditions to facilitate autolysis in OSA (Khursheed et al., 2015; Semblante et al., 2016a). Indeed the sCOD in the external reactors were 40-50\% and $90-95 \%$ lower than the sCOD and tCOD of the influent, respectively, implying that readily biodegradable substrate had already been consumed in the main aeration tank. Previous studies have shown that external anaerobic reactors possess a greater variety of microbial species than the main aerobic/anoxic reactor (Ning et al., 2014; Zhou et al., 2015), but the role of diversity in sludge reduction has not been fully elucidated. The results of this study imply that even though a fraction of the biomass undergoes decay under oxygen- and substrate-deficient conditions, microbial groups that are able to utilize lysates (i.e., products of cell lysis) or other food sources are enriched and eventually occupy a niche under environmental stress. These include hydrolyzing, fermentative, denitrifying, and predatory bacteria. The population of these microbial groups, specifically denitrifying and predatory bacteria, changed with $\mathrm{SRT}_{\text {ext }}$ and led to variation in sludge reduction. This is further discussed in Section 3.4.

\subsubsection{Microbial diversity of SBR ${ }_{\text {control }}$ and aerobic digester}

Under parallel conditions, the diversity of the single pass aerobic digester (labeled as AE) was similar to that of aerobic $\mathrm{SBR}_{\text {control }}$ when $\mathrm{SRT}_{\text {ext }}$ of the former was 10 (Phase III) and 20 
(Phase II) days (Table 2). On the contrary, the attached external reactors that had different redox regimes exhibited greater diversity than aerobic SBROSA. Notably, the aerobic digester was also under starvation conditions like the external reactors appended to SBRosA, but it had high DO concentration ( $>5 \mathrm{mg} / \mathrm{L}$ ) like $\mathrm{SBR}_{\text {control, }}$ and under the operating conditions of this study, the aerobic digestion did not reduce sludge. This indicates that the deficiency of both readily biodegradable substrate (which occurred in both external reactors of OSA and control aerobic digester) and oxygen (which occurred in external reactors of OSA only) were necessary to shift the microbial community structure and induce sludge reduction. Notably, the sCOD of the aerobic digester was approximately two times higher than that of the external reactors of OSA (Table 3) and $\mathrm{SBR}_{\text {control }}$ effluent (Table 1). This suggests that nonbiodegradable organic matter accumulated in the aerobic digester and was not consumed.

The diversity of the aerobic digester when the SRT ext $_{\text {was }} 40 \mathrm{~d}$ (Phase I) was lower than at 10 and $20 \mathrm{~d}$ (Table 2). Sludge with a long SRT (e.g., >60 d) tended to have high diversity because slow-growing bacteria have more opportunity to propagate (Ahmed et al., 2007). However, the diversity of aerated systems can also decrease when SRT is increased (e.g., from 2 to $8 \mathrm{~d}$ ) because the biomass stabilizes and microorganisms stop competing for resources (Saikaly et al., 2005). In this study, the decline in aerobic digester diversity at $\mathrm{SRT}_{\text {ext }}$ of $40 \mathrm{~d}$ coincided with the proliferation of the order Xanthomonadales that accounted for $72 \%$ of the biomass (to be discussed in Section 3.4.4). ORP and nutrient levels did not vary significantly in this phase (Table 2), but a slight change in $\mathrm{pH}$ possibly caused the proliferation of Xanthomonadales and other specific bacteria (to be discussed in Section 3.4.4).

\subsection{Impact of operational parameters: microbial community and sludge reduction}


PCoA was utilized to show the clustering of samples based on the differences in unweighted UniFrac distances (Figure 2). Close clustering indicates relative similarity in phylogenetically microbial structure of the samples. Results show that no single operating parameter can consistently explain the variation of microbial community between samples. The first two principal components (PC1, PC2) accounted for $43 \%$ of sample variation (Figure 2). However, a clear clustering of samples corresponded to redox condition, i.e., strictly aerobic (SBR ${ }_{O S A}, \mathrm{SBR}_{\text {control}}$, and the aerobic digester), intermittent aerobic, and strictly anoxic (Figure 2).

To further clarify the influence of operation parameters (i.e., redox condition, $\mathrm{SRT}_{\mathrm{ext}}$, and sludge interchange between aerobic and anoxic reactors) on the variation of microbial community structure, constrained analysis of principal coordinates (CAP) and Adonis were applied. The constrained model of redox condition, $\mathrm{SRT}_{\mathrm{ext}}$ and sludge interchange (i.e., OSA system vs. control system) (Supplementary Figure S4) showed a significant contribution of redox condition and $\mathrm{SRT}_{\mathrm{ext}}$ to the first two components in PCoA clustering of samples. For example, constraining redox condition and $\mathrm{SRT}_{\text {ext }}$ (Supplementary Figure S4a) explained nearly $85 \%$ as much variation as the first two unconstrained principal components of PCoA (e.g., $27 \%+10 \%$ in Supplementary Figure S4a vs. $29 \%+14 \%$ in Figure 2). Moreover, analysis of variance of unweighted UniFrac distance (Adonis) showed the contributions of redox condition (27\%), sludge interchange $(16 \%)$ and $\mathrm{SRT}_{\text {ext }}(12 \%)$ to the difference between microbial communities (Supplementary Table S5). The major role of redox condition on the development of microbial community in oxygen-deficient external reactors was also found in other sludge reduction systems (Kim et al., 2012; Niu et al., 2016).

\section{[Figure 2]}


Hierarchical clustering of unweighted UniFrac distances (Figure 3) showed that at $\mathrm{SRT}_{\text {ext }}$ of

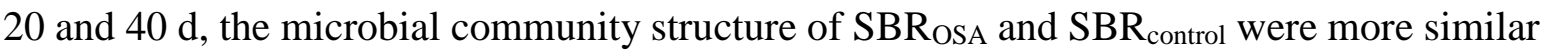
to each other than with their respective external reactors (Figure 2). This was probably because of interchange of lower volumes of sludge between SBROSA and the external anoxic

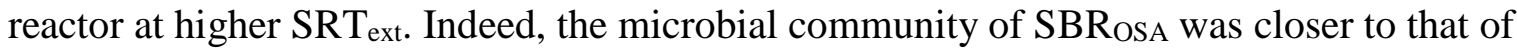
the external aerobic/anoxic reactor when SRT was $10 \mathrm{~d}$.

\section{[Figure 3]}

PCoA and clustering based on unweighted UniFrac showed that each unit of the SBRO system sustains the development of a unique microbial community according to redox regimes. $\mathrm{SRT}_{\mathrm{ext}}$ and sludge interchange between aerobic and anoxic reactors contributed to the dynamics of microbial communities between samples that explained the sludge reduction achieved by each unit and the systems. The correlation between variation of microbial community and the system performance was clarified further by examining more closely the shift in microbial phyla especially on the important functional groups in Section 3.4.

\subsection{Taxonomic classification and analysis}

Overall, 43 bacterial phyla and two archaeal phyla with relative abundance of less than $1 \%$ were detected in the OSA (SBROSA and external aerobic/anoxic and anoxic reactors) and

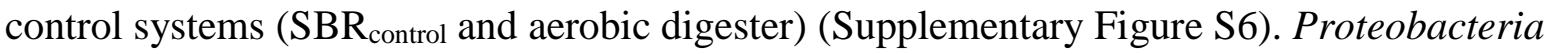
was the most dominant phylum (35-79\%) with $\gamma$-, $\beta$-, and $\alpha$-Proteobacteria as the predominant classes $(23 \pm 11 \%, 21 \pm 10 \%$, and $9 \pm 3 \%(\mathrm{n}=14)$, respectively). The second most abundant phylum was Bacteroidetes $(17 \pm 10 \%$; $\mathrm{n}=14)$ with Sphingobaceriia as the major class $(11 \pm 8 \% ; \mathrm{n}=14)$.

\subsubsection{Comparison of SBR ${ }_{0 S A}$ and $\mathrm{SBR}_{\text {control microbial composition }}$}




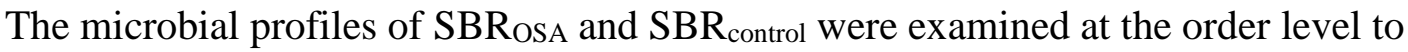
determine their relationship with sludge reduction. The SBRs had the same SRT (10 d) yet their microbial diversity (Section 3.2.1) and composition (Figure 4) varied significantly, which implicate the influence of sludge interchange on the microbial community of the main aeration tank. Xanthomonadales, Burkholdriales, Sphingobacteriales and Nitrospirales were the four predominant orders in both SBRs. Among these, nitrifying bacteria Nitrospirales was consistently more abundant in $\operatorname{SBR}_{\mathrm{OSA}}(2.4-8.9 \% ; \mathrm{n}=15)$ than $\mathrm{SBR}_{\text {control }}(0.1-3.9 \% ; \mathrm{n}=$ 15) in all phases of the study (Figure 4). Other nitrifying bacteria, Nitrosomonadales, was a minor constituent but was also consistently more abundant in SBROSA $(0.6-2.7 \% ; \mathrm{n}=15)$ than $\operatorname{SBR}_{\text {control }}(0.1-1.2 \% ; \mathrm{n}=15)$. Nitrifying bacteria inherently have slow growth rate (Tchobanoglus et al., 2003). The proliferation of slow-growing nitrifiers in SBRosA may contribute to the decrease of sludge yield. This is in addition to the sludge reduction due to the autolysis of sludge in the external reactors driven by the selection of distinct microbial groups (e.g., hydrolysers, fermenters, and bacterial predators).

\section{[Figure 4]}

A few_bacterial orders were more abundant in SBRosA than $S_{B} R_{\text {control }}$ under specific conditions. For example, Rhodospirillales was abundant when $\mathrm{SRT}_{\mathrm{ext}}$ was $40 \mathrm{~d}$ (Phase I). In contrast, some microbial orders were more abundant in SBR control $_{\text {than }}$ SBRosA, including Flavobacteriales when $\mathrm{SRT}_{\mathrm{ext}}$ was $40 \mathrm{~d}$ (Phase I) and Rhdobacterales when $\mathrm{SRT}_{\mathrm{ext}}$ was $20 \mathrm{~d}$ (Phase II). The random appearance of these bacteria was probably due to temporal variations in domestic wastewater strength and composition (Supplementary Table S1).

\subsubsection{Microbial community under oxygen-rich and -deficient conditions}


Variation in the abundance of Proteobacteria, Bacteroidetes, and other major phyla were primarily influenced by redox condition or ORP level, i.e., strictly aerobic (SBROSA,

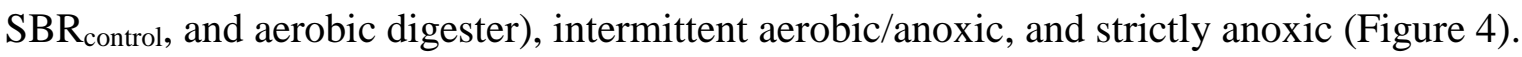
This is in agreement with the results of PCoA of unweighted UniFrac (Section 3.3).

The phylum Proteobacteria had lower abundance in oxygen-deficient than oxygen-rich conditions. The relative abundance of class $\beta$ - and $\gamma$-Proteobacteria decreased in the following order: aerobic ( $22 \pm 13$ and $29 \pm 20 \%, \mathrm{n}=9$, respectively) $>$ intermittent aerobic/anoxic $(19 \pm 6$. and $25 \pm 17 \%$, respectively; $\mathrm{n}=3)>$ anoxic $(12.9 \pm 1.4$ and $19 \pm 7 \%$, respectively; $\mathrm{n}=3$ ). Previous studies observed that the Proteobacteria population was negatively correlated with sludge reduction (Lin et al., 2009; Ning et al., 2014). Lin et al. (2009) reported that the relative abundance of $\beta$-Proteobacteria in a gravel contact oxidation reactor (12\%), a system that minimizes sludge production, was lower than that of a control CAS (18\%). Ning et al. (2014) noted that $\beta$-Proteobacteria was possibly the main bacterial class that was reduced in an external anaerobic reactor attached to a main anoxic/aerobic reactor. The current study indicates that both $\beta$ - and $\gamma$-Proteobacteria decayed under environmental stress in OSA. The decay of these microorganisms did not decrease the overall diversity of OSA (Section 3.2) because a greater variety of species were enriched under oxygen-deficient conditions. Moreover, the current study shows that both aerobic/anoxic and anaerobic treatment can enrich hydrolyzing and fermentative bacteria. This suggests that the addition of either anoxic or anaerobic external reactors can be used as an approach to reduce sludge.

The organisms that thrived under oxygen-deficient conditions included hydrolyzing and fermentative bacteria. Results show that the relative abundance of Bacteroidetes increased in the following order: aerobic $(14 \pm 9 \%, \mathrm{n}=9)>$ intermittent aerobic/anoxic $(16 \pm 9 \%, \mathrm{n}=3)>$ anoxic $(22 \pm 14 \%, \mathrm{n}=3)$ (Supplementary Figure S6). Members of Bacteroidetes are 
hydrolyzing bacteria that have been associated with EPS degradation (Ferrentino et al., 2016; Zhou et al., 2015). These bacteria have been detected in an external anaerobic reactors attached to main anoxic/aerobic reactors (Ferrentino et al., 2016; Zhou et al., 2015). Other hydrolyzing bacteria including members of the phyla Chloroflexi, Gemmatimonadetes and Chlorobi, were also more abundant in the anoxic $(2.4 \pm 0.6,2.0 \pm 0.6$ and $1.7 \pm 0.4 \%$, respectively; $\mathrm{n}=3$,$) and intermittently aerobic/anoxic (1.2 \pm 0.8,1.0 \pm 0.5$ and $0.8 \pm 1.0 \%$, respectively; $\mathrm{n}=3)$ than the aerobic $(0.1-0.6 \%)$ reactors (Supplementary Figure S6). Chloroflexi has been associated with anaerobic degradation of carbohydrates and cellular materials (Weissbrodt et al., 2014), and has been detected as one of the dominant bacteria in an external anaerobic reactor attached to an aerobic MBR (Cheng et al., 2017). Furthermore, fermentative bacteria such as OP8, Firmicutes, WS3, and Spirochaetae were only found in significant abundance in the external anoxic reactor $(2.2 \pm 1.2,1.0 \pm 0.1,1.0 \pm 0.5$ and $1.0 \pm$ $0.3 \%, \mathrm{n}=3$, respectively) (Supplementary Figure S6). Firmicutes degrades complex organic matter, and has been detected in an externa anaerobic reactor attached to anoxic/aerobic SBR (Ferrentino et al., 2016). Candidate phylum WS3 degrades a wide variety of polysaccharides and glycoproteins that are major components of EPS in activated sludge (Youssef et al., 2015). Hydrolysing and fermentative bacteria can function in tandem to facilitate sludge autolysis. Under oxygen-deficient conditions, hydrolyzing bacteria convert particulate or cellular organic matter into soluble sugars, monosaccharides, or fatty acids (Niu et al., 2016; Tchobanoglus et al., 2003). Meanwhile, fermentative bacteria break down products of hydrolysis into smaller fatty acids, alcohols, and other by-products (Ferrentino et al., 2016; Tchobanoglus et al., 2003). The abundance of hydrolyzing and fermentative bacteria especially in the external reactors bolster previous findings on the pertinent mechanisms of sludge autolysis in OSA, such as the destruction of volatile solids (Semblante et al., 2016a) and disintegration of EPS (Semblante et al., 2015). The current study provides a micro- 
ecological perspective on the mechanism of sludge autolysis in the external reactors: bacteria such as $\beta$ - and $\gamma$-Proteobacteria decrease in the external reactor, thereby producing materials that can be metabolized by hydrolyzing and fermentative bacteria for cell maintenance. The enrichment of hydrolyzers and fermenters further facilitates sludge autolysis as they break down particulate and soluble organic matter.

\subsubsection{Impact of external reactor SRT on microbial composition}

\subsubsection{OSA external reactors}

It was previously found that the external anoxic reactor induced sludge autolysis, while the external aerobic/anoxic reactor facilitated the conversion of destroyed volatile solids into inert materials via nitrification/denitrification (Semblante et al., 2016a). High nitrification/denitrification especially occurred in the external aerobic/anoxic reactor at low $\operatorname{SRT}_{\text {ext }}(<20$ d) (Supplementary Table S3) (Semblante et al., 2016b). Furthermore, increasing the $\mathrm{SRT}_{\text {ext }}$ decreased the ORP of the external aerobic/anoxic reactor when aeration was turned off (i.e., the anoxic phase) (Table 3) (Semblante et al., 2016b). In the current study, the relative abundance of the predominant order, Xanthomonadales ( $\gamma$-Proteobacteria), sharply increased from 16 to $43 \%$ when $\mathrm{SRT}_{\text {ext }}$ was increased from 10 to $20 \mathrm{~d}$, but declined to $12 \%$ when $\mathrm{SRT}_{\text {ext }}$ was further increased to $40 \mathrm{~d}$ (Figure 4). This indicates that Xanthomonadales thrives under environmental stress. Xanthomonadales has been detected in environments with low nitrogen (Atashgahi et al., 2015) and substrate content (Sato et al., 2016) such as one that pervades in the external aerobic/anoxic reactor at low $\mathrm{SRT}_{\text {ext }}(<20 \mathrm{~d})$ (Semblante et al., 2016b). Moreover, it has been found to increase when sludge production of an MBR decreased due to decline in organic loading (Sato et al., 2016). Although Xanthomonadales has been identified as a denitrifying bacteria (Ontiveros-Valencia et al., 2014) the current results show that denitrification efficiency was not necessarily enhanced (Supplementary Table S3) when it became more abundant. Other species could be responsible for 
denitrification in the aerobic/anoxic reactor. For instance the relative abundance $(16,6$, and $12 \%$ when $\mathrm{SRT}_{\text {ext }}$ was 10, 20, and 40 d, respectively; Figure 4) of denitrifying bacteria Burkhoderiales (Weissbrodt et al., 2014) correlated well with high denitrification (Supplementary Table S3). Nonetheless, bacteria having denitrifying capacity are notably diverse (Weissbrodt et al., 2014; Xu et al., 2015). Members of Rhodocyclales, Pseudomonadales, Rhodospirillales, Corynebacteriale, and Rhizobiales (Weissbrodt et al., 2014; Xu et al., 2015), which were all found in varying abundance in aerobic/anoxic sludge (Figure 4), can potentially perform denitrification. Therefore, it is possible that a consortium of bacteria performed denitrification in the aerobic/anoxic reactor.

Also of note, nitrifying bacteria (Nitrospirales and Nitrosomonadales) were detected in the external aerobic/anoxic reactor under all $\mathrm{SRT}_{\mathrm{ext}}$ (Figure 4). Nitrospirales accounted for 4 $8 \%$ of the biomass and Nitrosomonadales accounted for $1-2 \%$ (Figure 4 ). The abundance of nitrifying bacteria in the current study was higher than those detected in nitrifying activated sludge of a previous study (Phan et al., 2016). While Nitrosomonadales are well-known ammonia-oxidizing bacteria, a recent study found that Nitrospirales can perform complete nitrification (Daims et al., 2016). Therefore, the deficiency of nitrification/denitrification at $\mathrm{SRT}_{\text {ext }}$ of $40 \mathrm{~d}$ was not due to the loss of nitrifying species. Rather, it was because of the limitation of substrate (sCOD), corroborating the explanation in the previous study (Semblante et al., 2016b).

The families Saprospiraceae (14\%) and Chitinophagaceae (7\%) and the members of the order Sphingobacteriales, were the predominant bacteria in the external aerobic/anoxic reactor when $\mathrm{SRT}_{\text {ext }}$ was $40 \mathrm{~d}$. Members of Sphingobacteriales are aerobic or facultative anaerobic bacteria (Section 3.4.1). Increasing the $\mathrm{SRT}_{\mathrm{ext}}$ from 10 to $40 \mathrm{~d}$ decreased reactor ORP from approximately +50 to $-150 \mathrm{mV}$ when aeration was turned off (Table 3 ). This 
suggests that the ability of Sphingobacteriales to grow under anaerobic conditions (i.e., low ORP) enabled them to proliferate at high $\mathrm{SRT}_{\text {ext. }}$

A previous study showed that increasing SRT $_{\text {ext }}$ from 10 to $20 \mathrm{~d}$ enhanced volatile solids destruction in the external anoxic reactor, but further increasing $\mathrm{SRT}_{\text {ext }}$ to $40 \mathrm{~d}$ did not result in further solids destruction (Semblante et al., 2016b). In the current study, the microbial profile of this reactor helped in analyzing the impact of $\mathrm{SRT}_{\text {ext }}$ on sludge autolysis (Figure 4). Xanthomonadales $(18 \pm 7 \% ; \mathrm{n}=3)$ and Sphingobacteriales $(17 \pm 15 \% ; \mathrm{n}=3)$ were the predominant orders in the external anoxic reactor at all $\mathrm{SRT}_{\mathrm{ext}}$ (Figure 4). The relative abundance of nitrifying (Nitrosomonadales $=1.0 \pm 0.0 \%$ and Nitrospirales $=5.0 \pm 0.6 \% ; \mathrm{n}=$ 3) and denitrifying (Burkholderiales $=5.7 \pm 1.0 \% ; \mathrm{n}=3$ ) bacteria were similar at different $\mathrm{SRT}_{\text {ext }}$ (Figure 4). The population of these bacteria were stable because the ORP $(<400 \mathrm{mV})$ of the external anoxic reactor was maintained even though $\mathrm{SRT}_{\mathrm{ext}}$ was varied.

Predatory bacteria were especially enriched in the external anoxic reactor, and their population dynamics correlated with the efficiency of cell lysis in the external anoxic reactor. It was previously demonstrated that $20 \mathrm{~d}$ was the optimum $\mathrm{SRT}_{\text {ext }}$ for cell lysis in the external anoxic reactor (Semblante et al., 2016b). In line with that, in the current study we observed that Myxobacteriales were more abundant at $\mathrm{SRT}_{\mathrm{ext}}$ of $20 \mathrm{~d}(5.6 \%)$ than at $10(2.3 \%)$ and 40 d (3.6\%) (Figure 4). Myxobacteria, which are usually found in soils and aquatic environments, secrete metabolites to damage the cell wall of other bacteria (Yao et al., 2011). Likewise the abundance of Bdellovibrio, a genus of Gram-negative obligate predators that prey on other Gram-negative bacteria (Jurkevitch, 2007; Niu et al., 2016), was the highest when $\mathrm{SRT}_{\text {ext }}$ was $20 \mathrm{~d}(0.61 \% ; \mathrm{n}=3)$ (data not shown). Niu et al. (2016) also found Bdellovibrio and similar predatory bacteria in an oxygen-deficient tank attached to CAS to

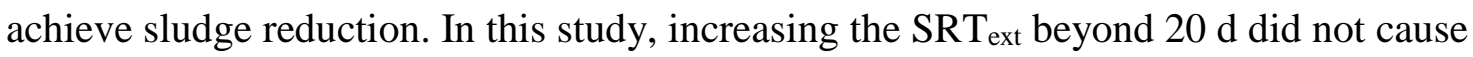
further improvement to cell lysis, possibly because the remaining biomass was able to survive 
using lysates as substrate under oxygen-deficient conditions. The abundance of predatory bacteria was at the maximum at $\mathrm{SRT}_{\text {ext }}$ of $20 \mathrm{~d}$ and slightly declined at $\mathrm{SRT}_{\text {ext }}$ of $40 \mathrm{~d}$, suggesting that their population was stable at $\mathrm{SRT}_{\mathrm{ext}} \geq 20 \mathrm{~d}$. The correlation between predatory bacterial population and cell lysis efficiency indicates that these microorganisms play a significant role in volatile solids destruction in the external anoxic reactor. Therefore, the enrichment and activity of predatory bacteria in the external reactors contribute to the overall sludge reduction in OSA.

The maximum abundance of certain hydrolyzing bacteria was observed at the $\mathrm{SRT}_{\text {ext }}$ of $20 \mathrm{~d}$. This pattern was especially observed in Chloroflexi, which had an abundance of 1.5, 4.3, and $1.4 \%$ at $\mathrm{SRT}_{\text {ext }}$ of 10,20 , and $40 \mathrm{~d}$, respectively. The current study indicates that in addition to predatory bacteria, hydrolyzing bacteria were essential to the process of sludge autolysis in OSA and other systems using redox interchange to reduce sludge. This also provides stronger evidence that anoxic condition is sufficient to induce the proliferation of hydrolyzing bacteria that facilitate sludge reduction.

\subsubsection{Control aerobic digester}

Similar to the external reactors of OSA, the aerobic digester was under substrate-deficient conditions (Section 3.2.3), however, minimal sludge autolysis occurred (Semblante et al., 2016b). In this study, the bacterial profile of the aerobic digester was analyzed to determine the impact of substrate deficiency on sludge with continuous supply of oxygen. This provides a point of comparison for assessing the synergistic effect of withholding both substrate and oxygen from sludge, as in the case of the external reactors of OSA.

PCoA showed that the microbial composition and structure of $\mathrm{SBR}_{\text {control }}$ and the aerobic digester were highly similar throughout the operating period (Section 3.3) except when $\mathrm{SRT}_{\text {ext }}$ was $40 \mathrm{~d}$ (Phase I). During this time, the low $\mathrm{pH}(<5.5)$ of the aerobic digester 
affected its microbial community. SBR control $_{\text {and }}$ aerobic digester had comparable microbial composition probably because the two reactors had similar DO concentration (> $5 \mathrm{mg} / \mathrm{L}$ ).

Also, the configuration of the control system, i.e., the aerobic digester received sludge solely

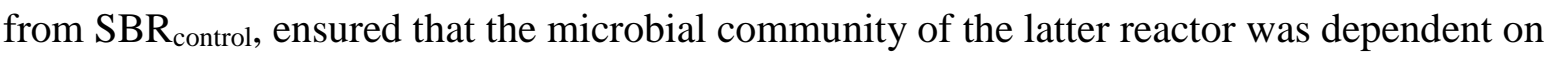
the former. However, a few bacteria had varying population in $\mathrm{SBR}_{\text {control }}$ and aerobic digester. For example, the percent composition of the orders Burkholderiales, Rhodocyclales, and Myxococcales in the aerobic digester $(7 \pm 6,7 \pm 6$ and $2.3 \pm 2.6 \%$, respectively; $\mathrm{n}=3$ ) was markedly lower than that of $\operatorname{SBR}_{\text {control }}(21 \pm 8,20 \pm 8$ and $13 \pm 8 \% ; n=3)$ (Figure 4). Their population probably diminished due to lack of readily biodegradable substrate in the aerobic digester. On the contrary, the percent composition of orders Xanthomonadales and Sphingobacteriales in the aerobic digester (42 \pm 27 and $11 \pm 7 \%$, respectively; $n=3$ ) was higher than that of $\operatorname{SBR}_{\text {control }}(13 \pm 9$ and $8 \pm 4 \%$, respectively; $\mathrm{n}=3)$. The aforementioned bacteria were also found at significant concentration in the external reactors of OSA (Section 3.4.3), suggesting that they can flourish despite the starvation conditions. These results indicate that although DO concentration is a key factor affecting microbial composition in sludge, the availability of substrate also contributes to shifts in microbial community structures.

Xanthomonadales $(35-70 \%)$ was the most abundant order in the aerobic digester at all SRTs (Figure 4). These bacteria were one of the four major orders in the SBRs (Section 3.4.2) and also the predominant order in the external aerobic/anoxic reactor of OSA (Section 3.4.3). Current findings suggest that Xanthomonadales can survive under substrate-deficient conditions.

Nitrification was inhibited in the aerobic digester (Semblante et al., 2016b) probably because bacteria that perform nitrification (e.g., Nitrospirales) and nitrogen-fixation or conversion of molecular nitrogen to ammonium ions (Rhiziobiales) were not abundant $(0-5 \%)$ at all 


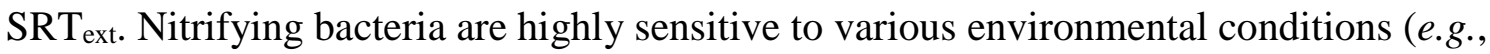
temperature, $\mathrm{pH}$, alkalinity, organic compounds). In this study, it is possible that the $\mathrm{pH}$ of the aerobic digester $(6.2-6.9)$ was too low for specific nitrifying bacteria to grow. For instance, $\mathrm{pH} 6.5-8.5$ is the ideal growth range for genus Nitrobacter, the bacteria that convert nitrite to nitrate (Gerardi, 2002). Possibly, the abundance of its parent order, Rhiziobiales, was very low $(0-2 \%)$ in the aerobic digester due to low $\mathrm{pH}$.

Some bacterial orders became more abundant when SRT ext was increased from 10 to $20 \mathrm{~d}$, and then declined when $\mathrm{SRT}_{\text {ext }}$ was increased to $40 \mathrm{~d}$. These included Sphingobacteriales, Flavobacteriales, Subgroup 4, and SC-I-84. Notably, with the exception of Spingobacteriales (5.8\%), the abundance of the aforementioned orders was nearly zero at SRT of $40 \mathrm{~d}$. Spinghobacteriales and Flavobacteriales are hydrolyzing bacteria that can break down carbohydrates (Maspolim et al., 2015; Ning et al., 2014).

The microbial diversity of the aerobic digester peaked at SRT ext $20 \mathrm{~d}$, and then sharply decreased at $\mathrm{SRT}_{\text {ext }}$ of $40 \mathrm{~d}$ (Section 3.2.3) with Xanthomonadales accounting for $72 \%$ of the community abundance. Xanthomonadales, as discussed earlier, are resilient bacteria that can survive under environmental stress involving oxygen and substrate deficiency (Figure 4). Another order that became predominant at $\mathrm{SRT}_{\mathrm{ext}}$ of $40 \mathrm{~d}$ was Acidobacteriales (11\%), which could survive under highly acidic conditions (Campbell, 2014). In this study, the pH of the aerobic digester ranged from $5.2-6.7$. The periods of low $\mathrm{pH}(<5.5)$ probably allowed this order to proliferate. Nonetheless, as mentioned in Section 3.2.3, the microbial diversity of the aerobic digester at this phase of the study was extremely low, so potential errors in sampling cannot be ruled out completely.

Generally, the patterns observed in the aerobic digester (i.e., lack of nitrification/ denitrification and sludge autolysis) were corroborated by its microbial diversity (Section 
3.2.3) and composition. The microbial profile of the aerobic digester also showed both substrate- and oxygen-deficient environments must be fulfilled to facilitate sludge autolysis in external reactors.

\section{Conclusion}

The microbial diversity and composition of a laboratory-scale OSA fed with real wastewater were determined. PCoA of unweighted Unifrac distances demonstrated that redox condition was the most important factor affecting microbial diversity. Microbial diversity in reactors increased in the following order: aerobic < intermittent aerobic/anoxic < anoxic. Generally, SBRosa had greater abundance of slow-growing nitrifying bacteria, which may explain the lower sludge yield compared to $\mathrm{SBR}_{\text {control. }}$ A wider range of microorganisms such as hydrolyzing (e.g., phyla Bacteroidetes and Chloroflexi), fermentative (e.g., orders OP8, Firmicutes, WS3, and Spirochaetae), and predatory (e.g., orders Myxobacteriales and Bdellovibrio) bacteria proliferated in the external reactors of OSA. Hydrolyzing and fermentative bacteria possibly facilitated the degradation of cellular matter. The increase in the abundance of predatory bacteria in the external anoxic reactor coincided with high sludge reduction under an optimum $\mathrm{SRT}_{\text {ext }}$ of $20 \mathrm{~d}$, suggesting that predators had a key role in facilitating sludge autolysis.

\section{Acknowledgements}

This research has been conducted with the financial support of the Australian Government Research Training Program Scholarship, Sydney Water, and TRILITY. The authors wish to thank a large number of Sydney Water's personnel, particularly Stewart Ramsay and his team 
at the Wollongong WWTP, New South Wales, Australia as well as Warwick Smith and his team at the Penrith WWTP, New South Wales, Australia for their logistic support. The authors are indebted to Prof. Nicholas E. Dixon of Centre for Medical and Molecular Bioscience, University of Wollongong for his review of the manuscript.

\section{References}

Ahmed Z, Cho J, Lim B-R, Song K-G, Ahn K-H. Effects of sludge retention time on membrane fouling and microbial community structure in a membrane bioreactor. Journal of Membrane Science 2007; 287: 211-218.

Anderson MJ, Willis TJ. Canonical analysis of principal coordinates: a useful method of constrained ordination for ecology. Ecology 2003; 84: 511-525.

Atashgahi S, Aydin R, Dimitrov MR, Sipkema D, Hamonts K, Lahti L, et al. Impact of a wastewater treatment plant on microbial community composition and function in a hyporheic zone of a eutrophic river. Scientific Reports 2015; 5: 17284.

Campbell BJ. The Family Acidobacteriaceae. In: Rosenberg E, DeLong EF, Lory S, Stackebrandt E, Thompson F, editors. The Prokaryotes: Other Major Lineages of Bacteria and The Archaea. Springer Berlin Heidelberg, Berlin, Heidelberg, 2014, pp. 405-415.

Caporaso JG, Bittinger K, Bushman FD, DeSantis TZ, Andersen GL, Knight R. PyNAST: a flexible tool for aligning sequences to a template alignment. Bioinformatics (Oxford, England) 2010a; 26: 266-267.

Caporaso JG, Kuczynski J, Stombaugh J, Bittinger K, Bushman FD, Costello EK, et al. QIIME allows analysis of high-throughput community sequencing data. Nature Methods 2010b; 7: 335-336.

Chen G-H, An K-J, Saby S, Brois E, Djafer M. Possible cause of excess sludge reduction in an oxic-settling-anaerobic activated sludge process (OSA process). Water Research 2003; 37: 3855-3866.

Cheng C, Zhou Z, Niu T, An Y, Shen X, Pan W, et al. Effects of side-stream ratio on sludge reduction and microbial structures of anaerobic side-stream reactor coupled membrane bioreactors. Bioresource Technology 2017; 234: 380-388.

Cydzik-Kwiatkowska A. Bacterial structure of aerobic granules is determined by aeration mode and nitrogen load in the reactor cycle. Bioresource Technology 2015; 181: 312320.

Daims H, Lücker S, Wagner M. A New Perspective on Microbes Formerly Known as NitriteOxidizing Bacteria. Trends in Microbiology 2016.

Eaton AD, Clesceri LS, Greenberg AE. Standard Methods for Examination of Water \& Wastewater. Washington DC: American Public Health Association, 2005.

Edgar R. Search and clustering orders of magnitude faster than BLAST. Bioinformatics 2010; 26: 2460 - 2461.

Edgar RC. UPARSE: highly accurate OTU sequences from microbial amplicon reads. Nat Meth 2013; 10: 996-998.

Ferrentino R, Langone M, Gandolfi I, Bertolini V, Franzetti A, Andreottola G. Shift in microbial community structure of anaerobic side-stream reactor in response to 
changes to anaerobic solid retention time and sludge interchange ratio. Bioresource Technology 2016; 221: 588-597.

Foladori P, Andreottola G, Ziglio G. Sludge reduction technologies in wastewater treatment plants. London: IWA Publishing, 2010.

Garrity GM, Bell JA, Lilburn T. Burkholderiales ord. nov. Bergey's Manual of Systematics of Archaea and Bacteria. John Wiley \& Sons, Ltd, 2015.

Gerardi M. Nitrification And Denitrification In The Activated Sludge Process. New York: J. Wiley, 2002.

Goel RK, Noguera DR. Evaluation of sludge yield and phosphorus removal in a Cannibal solids reduction process. Journal of Environmental Engineering 2006; 132: 13311337.

Jurkevitch E. Predatort Prokaryotes. In: Jurkevitch E, editor. Springer-Verlag Berlin Heidelberg, 2007.

Khursheed A, Sharma MK, Tyagi VK, Khan AA, Kazmi AA. Specific oxygen uptake rate gradient - Another possible cause of excess sludge reduction in oxic-settlinganaerobic (OSA) process. Chemical Engineering Journal 2015; 281: 613-622.

Kim YM, Chon D-H, Kim H-S, Park C. Investigation of bacterial community in activated sludge with an anaerobic side-stream reactor (ASSR) to decrease the generation of excess sludge. Water Research 2012; 46: 4292-4300.

Lin S, Wang Y, Lin J, Wang X, Gong H. Dominant bacteria correlated with elimination of sludge in an innovative reactor. Progress in Natural Science 2009; 19: 1765-1771.

Lozupone C, Knight R. UniFrac: A new phylogenetic method for comparing microbial communities. Applied and Environmental Microbiology 2005; 71: 8228-8235.

Maspolim Y, Zhou Y, Guo C, Xiao K, Ng WJ. Comparison of single-stage and two-phase anaerobic sludge digestion systems - Performance and microbial community dynamics. Chemosphere 2015; 140: 54-62.

McMurdie PJ, Holmes S. phyloseq: An R Package for Reproducible Interactive Analysis and Graphics of Microbiome Census Data. PLoS ONE 2013; 8: e61217.

Mowla D, Tran HN, Allen DG. A review of the properties of biosludge and its relevance to enhanced dewatering processes. Biomass and Bioenergy 2013; 58: 365-378.

Ning X, Qiao W, Zhang L, Gao X. Microbial community in anoxic-oxic-settling-anaerobic sludge reduction process revealed by 454 pyrosequencing analysis. Canadian Journal of Microbiology 2014; 60: 799-809.

Niu T, Zhou Z, Shen X, Qiao W, Jiang L-M, Pan W, et al. Effects of dissolved oxygen on performance and microbial community structure in a micro-aerobic hydrolysis sludge in situ reduction process. Water Research 2016; 90: 369-377.

Oksanen J, Blanchet FG, Kindt R, Legendre P, Minchin PR, O’Hara R, et al. Package 'vegan'. Community ecology package, version 2013; 2.

Ontiveros-Valencia A, Tang Y, Zhao H-P, Friese D, Overstreet R, Smith J, et al. Pyrosequencing Analysis Yields Comprehensive Assessment of Microbial Communities in Pilot-Scale Two-Stage Membrane Biofilm Reactors. Environmental Science \& Technology 2014; 48: 7511-7518.

Parte A, Krieg NR, Ludwig W, Whitman W, Hedlund BP, Paster BJ, et al. Bergey's Manual of Systematic Bacteriology: Volume 4: The Bacteroidetes, Spirochaetes, Tenericutes (Mollicutes), Acidobacteria, Fibrobacteres, Fusobacteria, Dictyoglomi, Gemmatimonadetes, Lentisphaerae, Verrucomicrobia, Chlamydiae, and Planctomycetes: Springer New York, 2011.

Phan HV, Hai FI, Zhang R, Kang J, Price WE, Nghiem LD. Bacterial community dynamics in an anoxic-aerobic membrane bioreactor - Impact on nutrient and trace organic 
contaminant removal. International Biodeterioration \& Biodegradation 2016; 109: 6172.

Price MN, Dehal PS, Arkin AP. FastTree 2 - Approximately maximum-likelihood trees for large alignments. PLoS ONE 2010; 5.

Pruesse E, Quast C, Knittel K, Fuchs BM, Ludwig W, Peplies J, et al. SILVA: a comprehensive online resource for quality checked and aligned ribosomal RNA sequence data compatible with ARB. Nucleic Acids Research 2007; 35: 7188-7196.

Saby S, Djafer M, Chen GH. Effect of low ORP in anoxic sludge zone on excess sludge production in oxic-settling-anoxic activated sludge process. Water Research 2003; 37: 11-20.

Saikaly PE, Stroot PG, Oerther DB. Use of $16 \mathrm{~S}$ rRNA gene terminal restriction fragment analysis to assess the impact of solids retention time on the bacterial diversity of activated sludge. Applied And Environmental Microbiology 2005; 71: 5814-5822.

Sato Y, Hori T, Navarro RR, Naganawa R, Habe H, Ogata A. Effects of Organic-LoadingRate Reduction on Sludge Biomass and Microbial Community in a Deteriorated PilotScale Membrane Bioreactor. Microbes and Environments 2016; 31: 361-364.

Semblante GU, Hai FI, Bustamante H, Guevara N, Price WE, Nghiem LD. Effects of iron salt addition on biosolids reduction by oxic-settling-anoxic (OSA) process. International Biodeterioration \& Biodegradation 2015; 104: 391-400.

Semblante GU, Hai FI, Bustamante H, Guevara N, Price WE, Nghiem LD. Biosolids reduction by the oxic-settling-anoxic process: Impact of sludge interchange rate. Bioresource Technology 2016a; 210: 167-173.

Semblante GU, Hai FI, Bustamante H, Price WE, Nghiem LD. Effects of sludge retention time on oxic-settling-anoxic process performance: Biosolids reduction and dewatering properties. Bioresource Technology 2016b; 218: 1187-1194.

Semblante GU, Hai FI, Ngo HH, Guo W, You S-J, Price WE, et al. Sludge cycling between aerobic, anoxic and anaerobic regimes to reduce sludge production during wastewater treatment: Performance, mechanisms, and implications. Bioresour. Technol 2014; 155: 395-409.

Singh NK, Kazmi AA, Starkl M. Treatment performance and microbial diversity under dissolved oxygen stress conditions: Insights from a single stage IFAS reactor treating municipal wastewater. Journal of the Taiwan Institute of Chemical Engineers 2016; 65: 197-203.

Spietz RL, Williams CM, Rocap G, Horner-Devine MC. A Dissolved Oxygen Threshold for Shifts in Bacterial Community Structure in a Seasonally Hypoxic Estuary. PLoS ONE 2015; 10: 1-18.

Stadler LB, Love NG. Impact of microbial physiology and microbial community structure on pharmaceutical fate driven by dissolved oxygen concentration in nitrifying bioreactors. Water Research In press.

Tchobanoglus G, Burton F, Stensel H. Wastewater engineering: Treatment and reuse. New York: American Water Works Association, 2003.

Weissbrodt DG, Shani N, Holliger C. Linking bacterial population dynamics and nutrient removal in the granular sludge biofilm ecosystem engineered for wastewater treatment. FEMS Microbiology Ecology 2014; 88: 579-595.

Xu G, Peng J, Feng C, Fang F, Chen S, Xu Y, et al. Evaluation of simultaneous autotrophic and heterotrophic denitrification processes and bacterial community structure analysis. Applied Microbiology and Biotechnology 2015; 99: 6527-6536.

Yadav TC, Khardenavis AA, Kapley A. Shifts in microbial community in response to dissolved oxygen levels in activated sludge. Bioresource Technology 2014; 165: 257264. 
Yao X, Xueming W, Ebright R, Wall D. Antibiotic Production by Myxobacteria Plays a Role in Predation. Journal of Bacteriology 2011; 193: 4626-4633.

Youssef NH, Farag IF, Rinke C, Hallam SJ, Woyke T, Elshahed MS. In Silico Analysis of the Metabolic Potential and Niche Specialization of Candidate Phylum Latescibacteria (WS3). PLoS ONE 2015; 10.

Zhou Z, Qiao W, Xing C, An Y, Shen X, Ren W, et al. Microbial community structure of anoxic-oxic-settling-anaerobic sludge reduction process revealed by $454-$ pyrosequencing. Chemical Engineering Journal 2015; 266: 249-257. 


\section{List of Figures}

Figure 1. Schematic diagram of (a) the OSA system comprised of SBRosa attached to intermittently aerated (i.e., aerobic/anoxic) and anoxic reactors, and (b) the control system (blank) comprised of $\mathrm{SBR}_{\text {control }}$ attached to a single-pass aerobic digester.

Figure 2. Principal coordinates of the unweighted UniFrac calculated at even sequencing depth of 50,000 sequences per sample. The samples were labeled as $\mathrm{X}$.Y, where $\mathrm{X}=$ reactor name and $\mathrm{Y}=\mathrm{SRT}_{\mathrm{ext}}$ (days). SBRoSA, aerobic/anoxic reactor, and anoxic reactor of the OSA system were

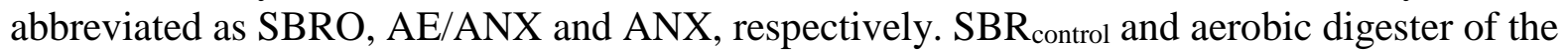
control system were abbreviated as SBRC and AE, respectively.

Figure 3. Sample clustering based on the unweighted UniFrac distance (calculated at even sequencing depth of 50,000 sequences per sample) at each $\mathrm{SRT}_{\mathrm{ext}}$ condition. The samples were labeled as $\mathrm{X}$.Y, where $\mathrm{X}=$ reactor name and $\mathrm{Y}=\mathrm{SRT}_{\mathrm{ext}}$ (days). SBROSA, aerobic/anoxic reactor, and anoxic reactor of the OSA system were abbreviated as SBRO, AE/ANX, and ANX, respectively. $\mathrm{SBR}_{\text {control }}$ and aerobic digester of the control system were abbreviated as SBRC and AE, respectively. The clustering (hclust) method used was "ward.D2."

Figure 4. The dominant microbial orders (above $2 \%$ in relative abundance) of the microbial communities in the main SBR and the external reactors. The samples were labeled as X.Y, where $\mathrm{X}=$ reactor name and $\mathrm{Y}=\mathrm{SRT}_{\mathrm{ext}}$ (days). $\mathrm{SBR}$ osA, aerobic/anoxic reactor, and anoxic reactor of the OSA system were abbreviated as SBRO, AE/ANX, and ANX, respectively. SBR control and aerobic digester of the control system were abbreviated as SBRC and AE, respectively. 
(a) OSA system
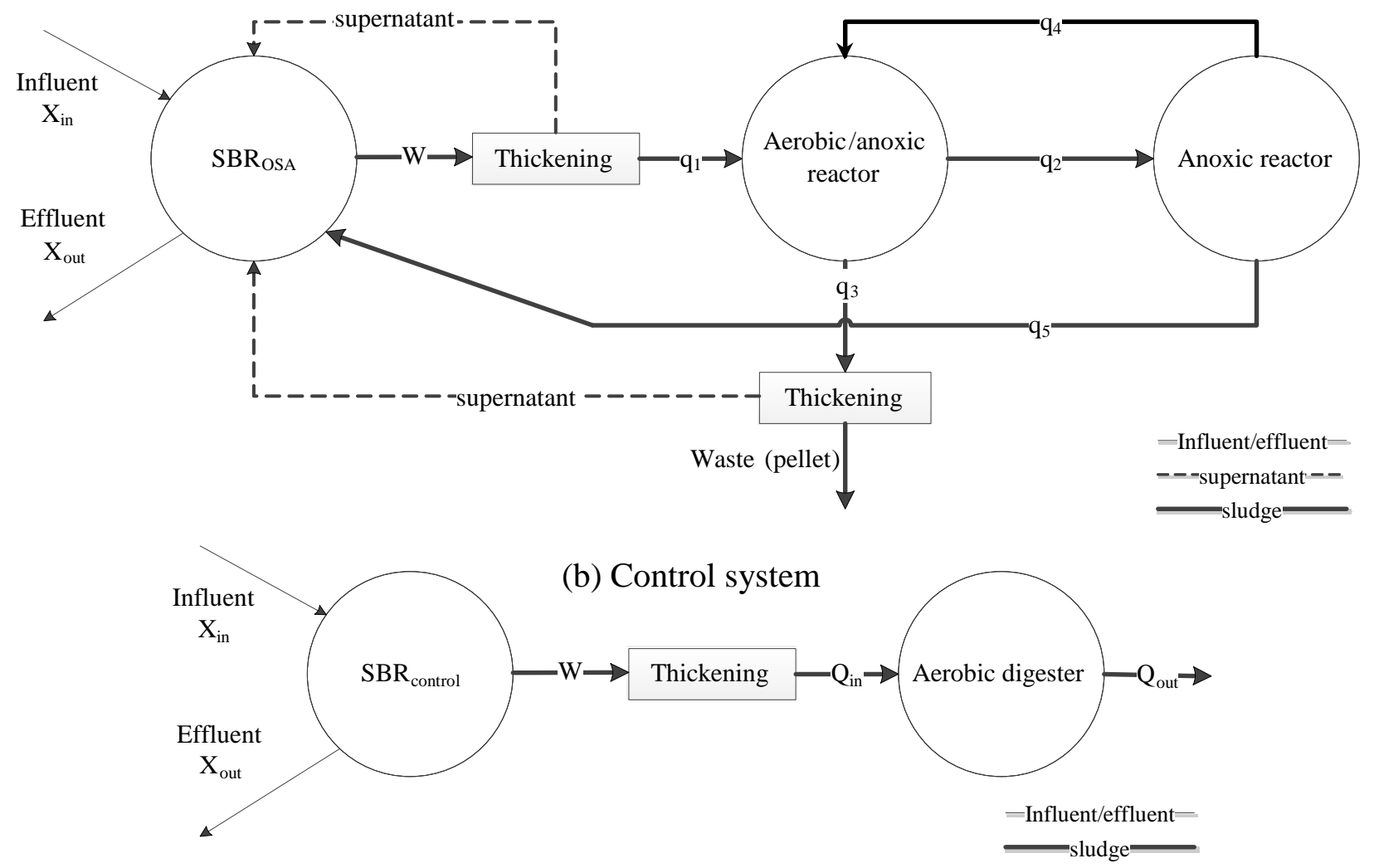

Figure 1 
Figure 2

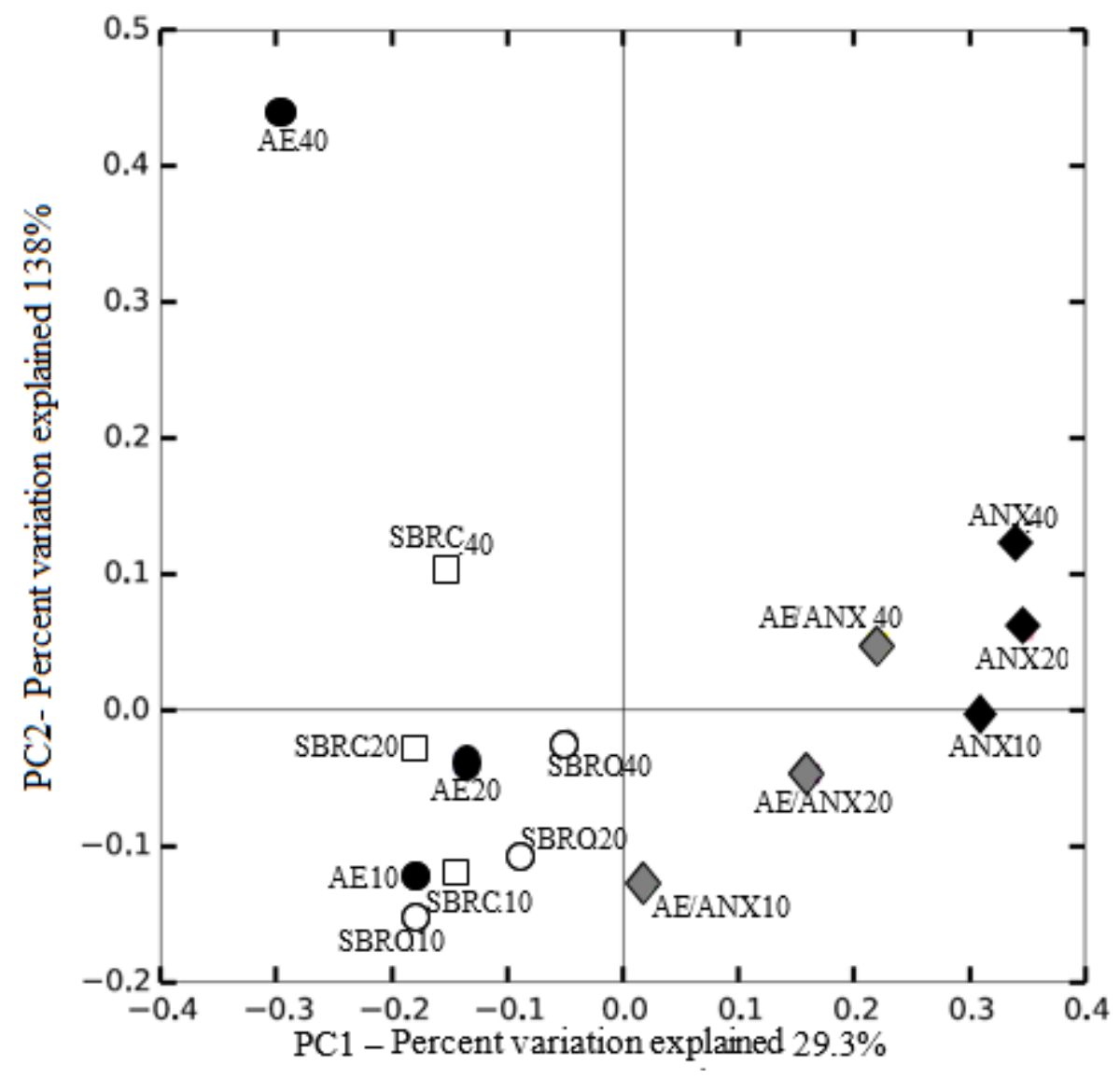



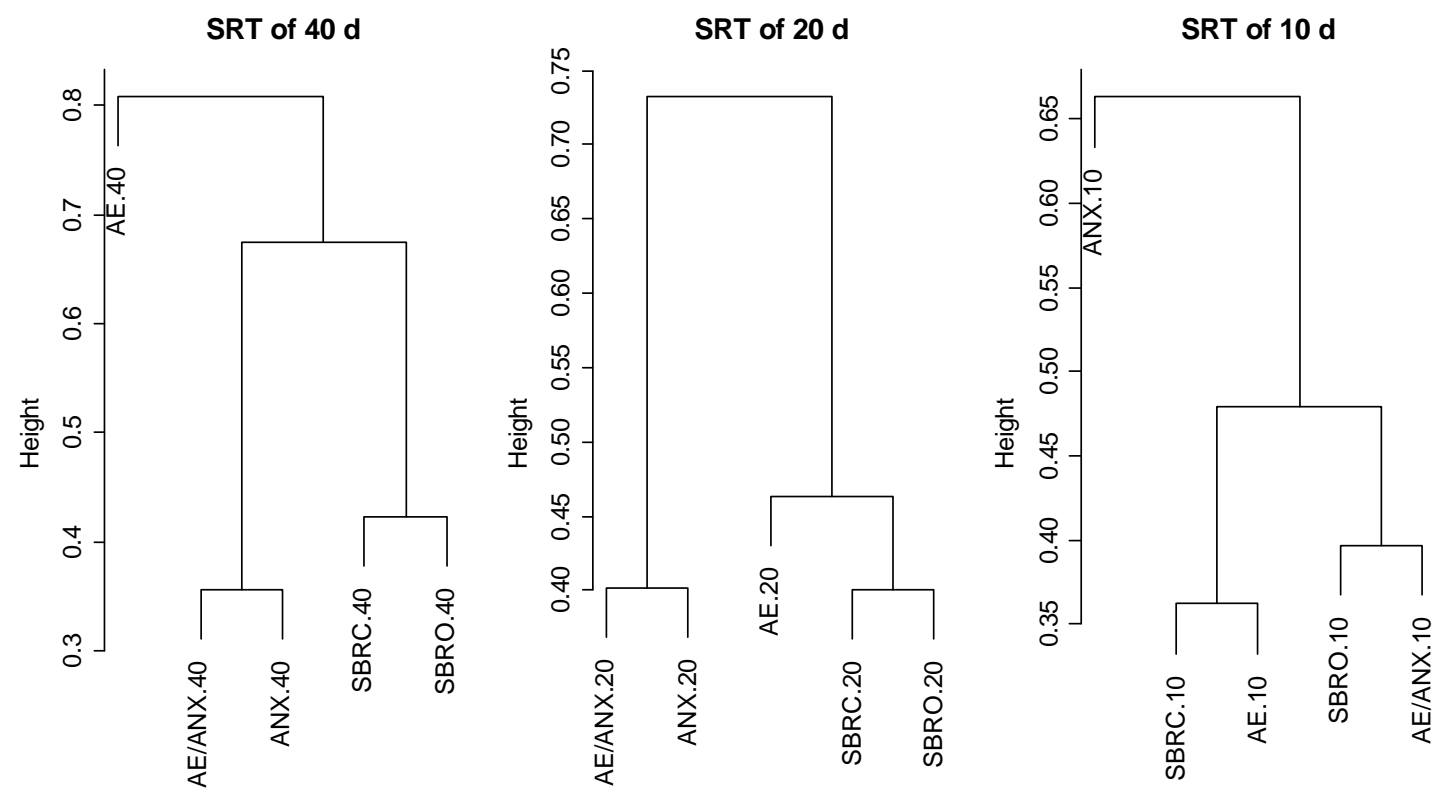

Figure 3 


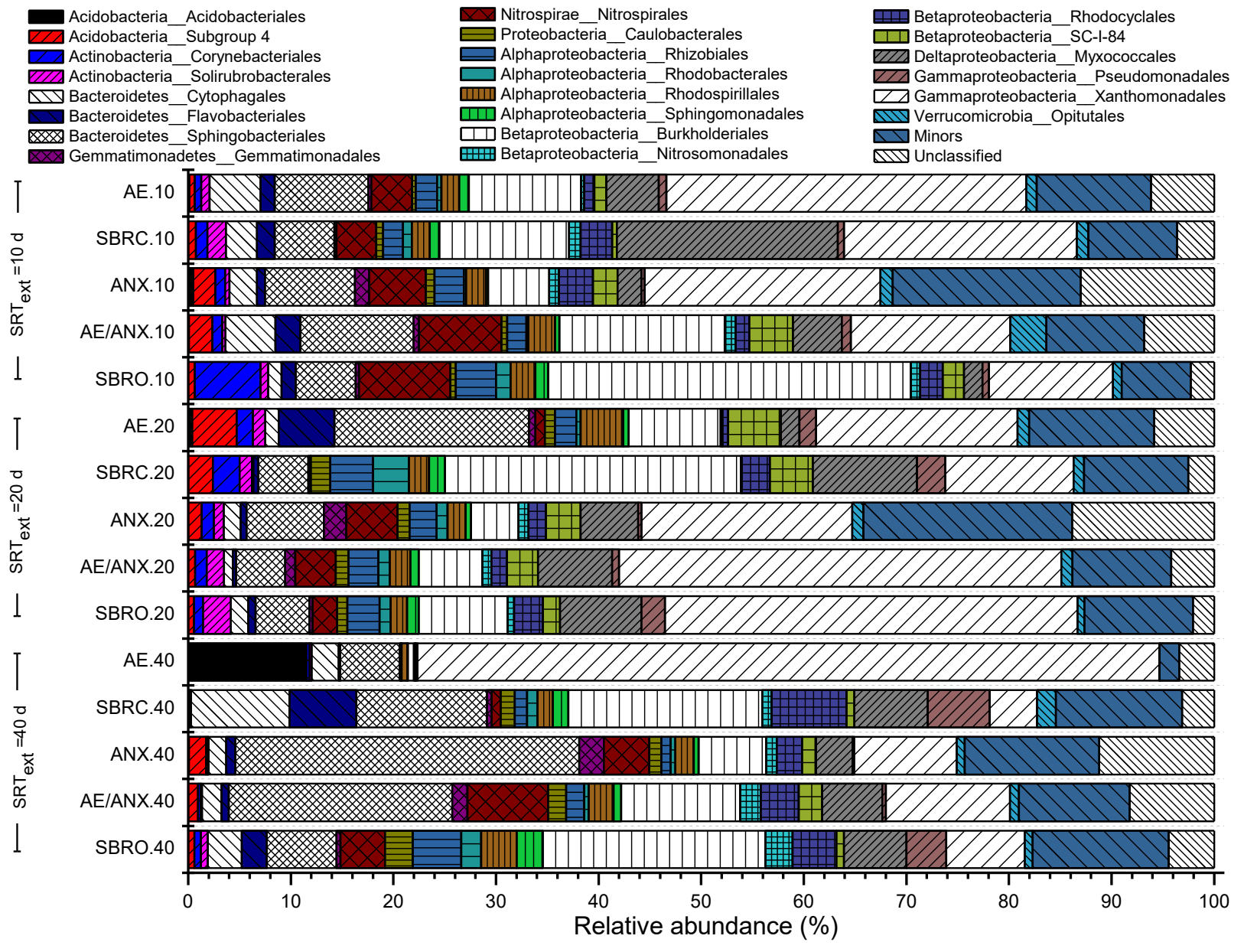

Figure 4 


\section{List of Tables}

Table 1. Summary of influent and effluent quality and sludge yield of OSA and control

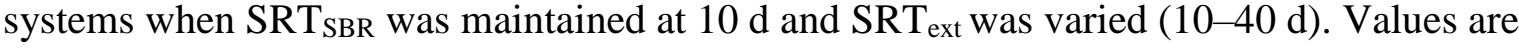
mean \pm standard deviation of $n$ number of samples.

Table 2. Microbial diversity indices in the OSA and control system reactors. Diversity was estimated at the minimum sequencing depth of all samples $(50,000$ sequences per sample). Coverage was more than $99 \%$ for all samples (data not shown). Values are mean \pm standard deviation of 10 iterations (10 random subsampling at sequencing depth of 50,000 sequences per sample).

Table 3. Operating conditions of OSA and control system reactors. Values are mean \pm standard deviation of $n$ number of samples. 
Table 1. Sludge yield $(Y)$ of SBRosa and $\mathrm{SBR}_{\text {control }}$ when $\mathrm{SRT}_{\mathrm{SBR}}$ was maintained at $10 \mathrm{~d}$ and $\mathrm{SRT}_{\text {ext }}$ was varied (10-40 d). Values are mean \pm standard deviation of $n$ number of samples.

\begin{tabular}{|c|c|c|c|c|c|c|c|c|c|c|c|}
\hline $\begin{array}{l}\text { Experimental } \\
\text { phase }\end{array}$ & $\begin{array}{l}\mathrm{SRT}_{\text {ext }} \\
\text { (d) }\end{array}$ & $\begin{array}{l}\text { Number } \\
\text { of } \\
\text { samples } \\
(n)\end{array}$ & Sample & $\begin{array}{l}\mathrm{tCOD} \\
(\mathrm{mg} / \mathrm{L})\end{array}$ & $\begin{array}{l}\mathrm{sCOD} \\
(\mathrm{mg} / \mathrm{L})\end{array}$ & $\begin{array}{c}\mathrm{NH}_{4}^{+}- \\
\mathrm{N} \\
(\mathrm{mg} / \mathrm{L})\end{array}$ & $\begin{array}{c}\mathrm{PO}_{4}^{3-}- \\
\mathrm{P} \\
(\mathrm{mg} / \mathrm{L})\end{array}$ & $\begin{array}{l}\text { TSS }(\mathrm{g} / \mathrm{L}) \\
\text { VSS }(\mathrm{g} / \mathrm{L})\end{array}$ & $\begin{array}{c}Y S B R O S A \\
(\mathrm{~g} \\
\text { MLVSS/g } \\
\text { tCOD }) ; \\
\left(R^{2}\right)\end{array}$ & $\begin{array}{c}Y S B R_{\text {control }} \\
(\mathrm{g} \\
\mathrm{MLVSS} / \mathrm{g} \\
\mathrm{tCOD}) ; \\
\left(R^{2}\right)\end{array}$ & $\begin{array}{l}\text { Sludge } \\
\text { yield } \\
\text { reduction } \\
(\%)\end{array}$ \\
\hline \multirow[b]{2}{*}{ I } & \multirow[b]{2}{*}{40} & \multirow[b]{2}{*}{18} & Influent & $498 \pm 208$ & $105 \pm 52$ & $86 \pm 36$ & $34 \pm 20$ & $\begin{array}{c}0.8 \pm 0.2 \\
0.3 \pm 0.1 \\
\end{array}$ & \multirow[b]{2}{*}{$\begin{array}{c}0.13 ; \\
(0.84)\end{array}$} & \multirow[b]{2}{*}{$\begin{array}{l}0.13 \\
(0.77)\end{array}$} & \multirow[b]{2}{*}{0} \\
\hline & & & $\begin{array}{l}\text { SBRosa } \\
\text { effluent }\end{array}$ & $78 \pm 38$ & $35 \pm 19$ & $10 \pm 7$ & $40 \pm 24$ & $\begin{array}{c}0.7 \pm 0.1 \\
0.2 \pm 0.1\end{array}$ & & & \\
\hline \multirow{3}{*}{ II } & \multirow{3}{*}{20} & \multirow{3}{*}{19} & Influent & $478 \pm 254$ & $99 \pm 56$ & $88 \pm 38$ & $29 \pm 8$ & $\begin{array}{c}0.7 \pm 0.1 \\
0.3 \pm 0.1\end{array}$ & \multirow{3}{*}{$\begin{array}{c}0.09 \\
(0.69)\end{array}$} & \multirow{3}{*}{$\begin{array}{l}0.14 \\
(0.80)\end{array}$} & \multirow{3}{*}{35} \\
\hline & & & $\begin{array}{l}\text { SBRosa } \\
\text { effluent }\end{array}$ & $75 \pm 29$ & $38 \pm 13$ & $12 \pm 5$ & $33 \pm 13$ & $\begin{array}{c}0.6 \pm 0.1 \\
0.2 \pm 0.1\end{array}$ & & & \\
\hline & & & $\begin{array}{c}\text { SBR }_{\text {control }} \\
\text { effluent }\end{array}$ & $89 \pm 55$ & $44 \pm 28$ & $14 \pm 11$ & $34 \pm 11$ & $\begin{array}{c}0.6 \pm 0.2 \\
0.2 \pm 0.1\end{array}$ & & & \\
\hline III & 10 & 11 & $\begin{array}{c}\text { SBR }_{\text {control }} \\
\text { effluent }\end{array}$ & $64 \pm 26$ & $47 \pm 22$ & $8 \pm 4$ & $19 \pm 2$ & $\begin{array}{c}0.7 \pm 0.1 \\
0.2 \pm 0.1\end{array}$ & $\begin{array}{c}0.16 \\
(0.67)\end{array}$ & $\begin{array}{l}0.19 \\
(0.65)\end{array}$ & 16 \\
\hline
\end{tabular}


Table 2. Microbial diversity indices in the OSA and control system reactors. Diversity was estimated at the minimum sequencing depth of all samples (50,000 sequences per sample). Coverage was more than $99 \%$ for all samples (data not shown). Values are mean \pm standard deviation of 10 iterations (10 random subsampling at sequencing depth of 50,000 sequences per sample).

\begin{tabular}{|c|c|c|c|c|c|c|c|}
\hline Experimental phase & $\mathrm{SRT}_{\text {ext }}(\mathrm{d})$ & Reactor & Sample label & OTUs & Chao1 & PD & Shannon \\
\hline \multirow{4}{*}{ I } & \multirow{4}{*}{40} & SBRosA & SBRO.40 & $1630 \pm 15$ & $2055 \pm 75$ & $83 \pm 1$ & $8.2 \pm 0.01$ \\
\hline & & Aerobic/anoxic & AE/ANX.40 & $1870 \pm 10$ & $2330 \pm 40$ & $100 \pm 1$ & $7.8 \pm 0.01$ \\
\hline & & Anoxic & ANX.40 & $2085 \pm 20$ & $2700 \pm 70$ & $119 \pm 2$ & $7.9 \pm 0.01$ \\
\hline & & Aerobic digester & AE.40 & $450 \pm 10$ & $730 \pm 65$ & $35 \pm 1$ & $3.3 \pm 0.01$ \\
\hline \multirow{3}{*}{ II } & \multirow{3}{*}{20} & SBR OSA & SBRO.20 & $1350 \pm 2$ & $1680 \pm 10$ & $72 \pm 0$ & $6.40 \pm 0.01$ \\
\hline & & $\mathrm{SBR}_{\text {control }}$ & SBRC.20 & $1210 \pm 10$ & $1530 \pm 30$ & $64 \pm 1$ & $7.0 \pm 0.01$ \\
\hline & & Aerobic digester & AE.20 & $1245 \pm 3$ & $1565 \pm 15$ & $67 \pm 0$ & $7.3 \pm 0.01$ \\
\hline \multirow{4}{*}{ III } & \multirow{4}{*}{10} & SBR OSA & SBRO.10 & $985 \pm 10$ & $1265 \pm 40$ & $54 \pm 1$ & $6.0 \pm 0.01$ \\
\hline & & Aerobic/anoxic & AE/ANX.10 & $1325 \pm 10$ & $1650 \pm 40$ & $75 \pm 1$ & $7.3 \pm 0.01$ \\
\hline & & Anoxic & ANX.10 & $2010 \pm 10$ & $2490 \pm 40$ & $114 \pm 1$ & $7.9 \pm 0.01$ \\
\hline & & $\mathrm{SBR}_{\text {control }}$ & SBRC.10 & $1190 \pm 10$ & $1450 \pm 30$ & $64 \pm 1$ & $6.8 \pm 0.01$ \\
\hline
\end{tabular}


Table 3. Operating conditions and properties of OSA and control system reactors. Values are mean \pm standard deviation of $n$ number of samples.

\begin{tabular}{|c|c|c|c|c|c|c|c|c|c|}
\hline $\begin{array}{l}\text { Experimental } \\
\text { phase }\end{array}$ & $\mathrm{SRT}_{\mathrm{ext}}$ & $\begin{array}{l}\text { Number of } \\
\text { samples }(n)\end{array}$ & Reactor & $\mathrm{pH}$ & ORP $(\mathrm{mV})$ & $\mathrm{DO}(\mathrm{mg} / \mathrm{L})$ & $\begin{array}{l}\text { SCOD }^{a} \\
(\mathrm{mg} / \mathrm{L})\end{array}$ & $\begin{array}{c}\text { MLSS } \\
(\mathrm{g} / \mathrm{L})\end{array}$ & $\begin{array}{c}\text { MLVSS } \\
(\mathrm{g} / \mathrm{L})\end{array}$ \\
\hline \multirow{5}{*}{ I } & \multirow{5}{*}{40} & \multirow{5}{*}{18} & SBROSA & $6.5 \pm 0.7$ & $230 \pm 60$ & $6.4 \pm 0.6$ & - & $2.6 \pm 1.0$ & $1.8 \pm 0.6$ \\
\hline & & & Aerobic/anoxic & $6.7 \pm 0.3$ & $\begin{array}{c}140 \pm 10 / \\
-120 \pm 20^{b}\end{array}$ & $\begin{array}{l}5.5 \pm 0.5 / \\
0.3 \pm 0.2 \mathrm{~b}\end{array}$ & $67 \pm 49$ & $5.2 \pm 2.0$ & $3.5 \pm 1.5$ \\
\hline & & & Anoxic & $6.5 \pm 0.4$ & $-410 \pm 20$ & - & $40 \pm 7$ & $2.9 \pm 1.0$ & $1.9 \pm 0.8$ \\
\hline & & & $\mathrm{SBR}_{\text {control }}$ & $6.6 \pm 0.4$ & $220 \pm 20$ & $5.6 \pm 0.8$ & - & $2.2 \pm 1.0$ & $1.7 \pm 0.8$ \\
\hline & & & Aerobic digester & $6.3 \pm 0.6$ & $200 \pm 70$ & $5.6 \pm 1.3$ & $109 \pm 60$ & $9.9 \pm 3.2$ & $6.7 \pm 2.3$ \\
\hline \multirow{5}{*}{ II } & \multirow{5}{*}{20} & \multirow{5}{*}{19} & SBRoSA & $7.2 \pm 0.6$ & $230 \pm 40$ & $6.4 \pm 1.0$ & - & $2.3 \pm 0.8$ & $1.7 \pm 0.7$ \\
\hline & & & Aerobic/anoxic & $6.9 \pm 0.4$ & $\begin{array}{c}90 \pm 30 / \\
-40 \pm 120^{\mathrm{b}}\end{array}$ & $\begin{array}{l}5.0 \pm 1.4 / \\
0.3 \pm 0.1^{\mathrm{b}}\end{array}$ & $43 \pm 19$ & $3.8 \pm 1.2$ & $2.7 \pm 0.9$ \\
\hline & & & Anoxic & $6.5 \pm 0.3$ & $-430 \pm 10$ & - & $45 \pm 19$ & $3.9 \pm 1.1$ & $2.6 \pm 0.8$ \\
\hline & & & $\mathrm{SBR}_{\text {control }}$ & $7.3 \pm 0.6$ & $220 \pm 20$ & $6.0 \pm 1.2$ & - & $7.3 \pm 1.7$ & $5.0 \pm 1.2$ \\
\hline & & & Aerobic digester & $6.4 \pm 0.4$ & $190 \pm 40$ & $6.9 \pm 1.1$ & $153 \pm 23$ & $5.0 \pm 1.2$ & $0.7 \pm 0.1$ \\
\hline \multirow{5}{*}{ III } & \multirow{5}{*}{10} & \multirow{5}{*}{11} & SBRosA & $6.8 \pm 0.4$ & $220 \pm 40$ & $6.0 \pm 0.6$ & - & $2.1 \pm 0.2$ & $1.6 \pm 0.2$ \\
\hline & & & Aerobic/anoxic & $6.2 \pm 0.5$ & $\begin{array}{l}130 \pm 60 / \\
50 \pm 20^{\mathrm{b}}\end{array}$ & $\begin{array}{l}3.9 \pm 0.2 / \\
0.3 \pm 0.1 \mathrm{~b}\end{array}$ & $60 \pm 33$ & $2.0 \pm 0.4$ & $1.5 \pm 0.2$ \\
\hline & & & Anoxic & $6.2 \pm 0.2$ & $-390 \pm 60$ & - & $25 \pm 60$ & $2.1 \pm 0.7$ & $1.4 \pm 0.5$ \\
\hline & & & $\mathrm{SBR}_{\text {control }}$ & $6.9 \pm 0.3$ & $220 \pm 40$ & $4.9 \pm 0.8$ & - & $2.2 \pm 0.2$ & $1.6 \pm 0.2$ \\
\hline & & & Aerobic digester & $6.9 \pm 0.5$ & $120 \pm 40$ & $4.7 \pm 0.6$ & $87 \pm 48$ & $3.8 \pm 1.0$ & $2.5 \pm 0.4$ \\
\hline
\end{tabular}

${ }^{a}$ Refers to SCOD of the mixed liquor supernatant

${ }^{\mathrm{b}}$ ORP and DO measurements during aeration 